\section{Sodium Sulphate as an Agent Causing the Development of the 'Chloride-secreting Cells' in Macropodus}

IN an earlier paper ${ }^{1}$, I have reported the enormous development of the 'chloride-secreting cells' in the branchial lamellæ of the paradise fish acclimatized in a table-salt solution of salinity $27 \cdot 3$ per cent. As these cells are very scanty and rudimentary in the control specimens, the conclusion was drawn, in harmony with the suggestion of Keys and Willmer ${ }^{2}$, that they are intimately concerned in the undertaking of osmotic regulation against a hypertonic external medium. The question now arises as to whether the secretory activity of these cells is restricted to chloride alone, as their name implies, or is of a more general nature, capable of turning out salts other than chloride.

To shed light on this problem, I have conducted an acclimatization experiment on Macropodus opercularis similar to that described in the earlier paper (vide supra), except that Merck's extra pure crystals of Glauber's salt $\left(\mathrm{Na}_{2} \mathrm{SO}_{4} \cdot 10 \mathrm{H}_{2} \mathrm{O}\right)$ was employed in substitution for the table-salt. Commencing on March 12, 1942, $0.5 \mathrm{gm}$. of that salt was introduced daily into the 3,000 c.c. jar, which housed four individuals, until May 10 inclusive. Then the daily dose was increased to $1 \mathrm{gm}$. from May 11 to May 20 inclusive, to $2 \mathrm{gm}$. from May 21 to June 9 inclusive, to $3 \mathrm{gm}$. from June 10 to June 19 inclusive, and up to $4 \mathrm{gm}$. from June 20 to June 24 inclusive. At the close of the course of acclimatization, the milieu extérieur was composed of a Glauber's salt solution of $3 \cdot 83$ per cent strength (since a total of $115 \mathrm{gm}$. had been dissolved in 3,000 c.c. of water), and in this the fish lived, apparently with depressed appetite, for four days before they were killed and their gills fixed (on June 29). Microscopic examination revealed quite a number of the 'chloride-secreting cells' at the base of the branchial lamellr, the larger ones of which sometimes measured $12 \mu \times 9 \mu$ in size. Although not so prominent as those acclimatized in the table-salt solution, these cells are clearly evident and much more well-developed in comparison with the control specimen, so it is scarcely possible for them to be wrongly identified.

The result thus obtained points to a non-specificity of the secretory activity of these cells. As the external medium is practically chloride-free and owes its osmotic gradient exclusively to the sulphate, there is no reason to think that these cells should secrete chloride instead of sulphate under such a condition. The development of such cells in a hypertonic sulphate solution can most easily be interpreted on the assumption that these cells are secreting the sulphate, for in this way water could be freed and osmo-regulation effected. Accordingly, I suggest that the substance destined to be secreted would not necessarily be chloride in all instances, but would vary according to the chemical nature of the environment, and would probably correspond to the osmotically active substance in the external medium. In the case of a marine environment, the osmotically active substance is naturally the chloride, hence chloride is secreted by these cells ${ }^{3}$. In the present experiment, however, sulphate should be expected, inasmuch as it is the only osmotically active substance present.

That the 'chloride-secreting cells' develop in response to a sulphate medium tends to weaken the conclusion reached by $\mathrm{Smith}^{4}$ that " $\mathrm{SO}_{4}$, like $\mathrm{Ca}$, $\mathrm{Mg}$ and $\mathrm{PO}_{4}$, is excreted exclusively by the kidneys".
According to his opinion, sulphate should combine with sodium, to be excreted afterwards by the kidney, as he puts it : "In the absence of other salts, $\mathrm{SO}_{4}$ takes $\mathrm{Na}$ into the urine with it, ..." If so, then the burden of osmotic regulation in a hypertonic sulphate solution would appear to have been borne by the renal organs rather than the gills. But this is wellnigh impossible in view of the osmotic limitation of the fish kidney. Based on the result of the present experiment, considering the 'chloride-secreting cells' as the anatomical basis for hypertonic excretion, I suggest that divalent ions, at least the sulphate, might also be secreted extra-renally by these cells. Determination of the secretion of these cells by direct chemical methods is much required to settle this question.

I wish to express my gratitude to Dr. H. W. Wu, at whose suggestion the present work was carried out.

National Institute of Zoology and Botany, C. K. LIU. Academia Sinica.

${ }^{1}$ Iiu, C. K., Sinensia, 13, 15 (1942).

Keys, A. B., and Willmer, E. N., J. Physiol., 76, 368 (1932).

${ }^{3}$ Keys, A. B., Z. vergl. Physiol., 15, 364 (1931).

- Smith, H. W., Amer. J. Physiol., 93, 480 (1930).

\section{Congenital Porphyria in Pigs}

Congenrtal porphyria in animals was first described by Fourie and Rimington ${ }^{1}$, who found the condition in cattle in South Africa. The most striking features of the disease are the colour of the bones due to the deposition of uroporphyrin and other pigments, and the excretion of considerable amounts of porphyrin in urine and faeces. The finding of such pigmented bones in cattle and swine in slaughterhouses has been reported from time to time (for review see ref. 2), but so far as we are aware no living domestic animals other than South African cattle have been available for study.

Recently, some pig bones showing a reddishbrown discoloration were sent to the Animal Research Station, Wallaceville, by Mr. J. A. Chenery, supervising meat inspector at Waitara. The bones gave a brilliant red fluorescence in ultra-violet light and were found to contain uroporphyrin I. Congenital porphyria was therefore suspected. When a second pig from the same farm was found to show similar symptoms, it was possible to trace the sow which was producing offspring with pigmented bones. A urine sample from this sow was dark red, with absorption bands, after acidification, at 555 and 600 $\mathrm{m} \mu$, and on extraction yielded uroporphyrin $I$ and coproporphyrin I, together with small amounts of the series III isomers. The fæces contained coproporphyrin I and traces of coproporphyrin III.

Full details of the chemical examination of material from this sow and affected progeny will be given elsewhere; here it is sufficient to state that the nature and type of the porphyrins obtained resemble those found in human and bovine congenital porphyria. The sow appears to be the first living case of congenital porphyria in pigs which has been examined.

Fourie $^{3}$ has shown that in South African cattle the disease is inherited as a recessive character. Information so far available on the breeding of the pigs is incomplete, and no conclusions as to the mode of inheritance can be drawn. The affected sow is of mixed breeding, out of a Tamworth-Berkshire- 